\section{Genomanalyse und Gentherapie}

\author{
Edited by Hans-Martin Sass, \\ 347 pages, Berlin-Heidelberg, \\ DM98.00, Springer-Verlag, 1991
}

These proceedings of a conference on genome analysis and gene therapy (Bochum, FRG, 1989) represent an impressive array of analytical papers that thoroughly cover the field in its technical, legal and bioethical aspects. The material is necessarily of uneven quality, at times repetitious and not always original, but most positions are solidly argued and adequately referenced.

Genome analysis is presented as reasonably acceptable, but information gained can obviously be used in controversial ways: Can defective embryos be aborted? Will genetic predispositions lead to discrimination in the job market or in contracting insurance coverage? Will genetically determined potential disease unleash social demands that such individuals assume an extra share of self-protection? Could public interest make genome analysis mandatory? In posing these questions, the different authors make it clear that the ethics of genome analysis are to be separated from the far more encompassing problems of how to dispose of the knowledge thus gained.

A strong and optimistic argument tries to dissect fear of knowledge from distrust about its applications. Genome mapping is not nourished by some malignant or controversial desire to change the genetic endowment of human beings. Eugenics have been misused in a monstruous fashion, but nothing of this kind is implicit in contemporary genetic research. Fears considered unreasonable are jeopardising the possibility of learning how to avoid such maiming conditions as sickle-cell disease. Research is not to be restricted, but political control of its applications should be flexible and efficient.

It is understandable that researchorientated and therapeutically-sensitive interests should view political control of genetic research as paralysing and unfair to potential beneficiaries. But, as other contributors in this volume state, regulation of research projects may be ignored or circumvented by privately funded laboratories and, furthermore, there is no convincing historic precedent to show that knowledge, once secured, will lie dormant because dire consequences must be expected from its application. All contributors agree that gene technology is to be restricted to the control of disease, avoiding so-called enhancement genetic engineering, which, incidentally, is practised in some countries and approved of by a substantial number of doctors and ethicists for the purpose of sex determination.

Most arguments in this area are of a utilitarian kind and therefore inconclusive, but deontological stances carry the day on one issue only: it is agreed that eventual approval of gene therapy must remain restricted to somatic cell genes, definitely excluding germ-line cell manipulation, on the basis of $\mathrm{H}$ Jonas's concern about irreversible, illegitimate and unauthorised interference with future generations.

In sum, this collection of essays competently represents current views on the controversial issues of gene technology and, although not offering new insights, it should serve as a comprehensive and timely review of current thoughts on the matter.

MICHAEL H KOTTOW, Professor of Ophthalmology, University of Chile.

\section{In-vitro Fertilisation - ein Umstrittenes Experiment}

Christina Höelzle and Urban Wiesing, 111 pages, Berlin-Heidelberg, DM38.00, Springer-Verlag, 1991

This is a fairly short but thoroughly referenced text on the facts, values and ethics of IVF. The main argument develops from the awareness that only 1 in 10 IVFs will lead to the birth of a child, an incidence that is lower than spontaneous births in presumed infertile couples. The authors conclude that indications for IVF have been too broadly set and can only remain undisputed in the bilateral absence of Fallopian tubes. Apparent success is further clouded by a number of complications, including iatrogenic damage during surgical manipulation, ectopic multiple pregnancies and malformed babies.

Infertility may result from predominantly psychological rather than organic causes, constituting a classical psychosomatic disorder not amenable to strictly medico-technical approaches. IVF ignores the fact that infertile couples live under emotional duress and a sensation of social inadequacy, erroneously concentrating on the strictly biological issue of reproduction. Under these circumstances, therapeutic failure may increase the emotional instability of the couple, whereas success will often leave remnants of social and familial maladjustment.

Hölzle and Wiesing come to the conclusion that childlessness is not a disease, the abnormality lying rather in the couples' attitude towards their barrenness. At this point, their already biased argumentation becomes flatly ad hoc: organisms, being teleologic in a Kantian sense, will originate protective reactions whenever necessary. Infertile couples must therefore consider the possibility that nature's wisdom in denying them reproduction should not be tampered with.

If IVF is an established form of therapy, it is being much too liberally indicated, especially in view of its low success rate and inefficient cost/benefit ratio. On the other hand, there is no justification for applying IVF on an experimental basis, since results have been consistently poor and therefore too little benefit accrues to patients to justify continued research.

No doubt, the authors of this book are against IVF, at least in its prolific, service-orientated form. They have relied heavily on medico-technical data to state that IVF is not an adequate tool against infertility unless a strict indications policy and adequate information are adhered to. This is a reasonable and uncontroversial demand, valid for all sorts of medical practices.

Strictly ethical issues are covered insufficiently or not at all: little is said about surplus embryos, nothing about the moral status of implanted zygotes or about the possible dilemma of considering abortion if malformations should develop or be detected. IVF has been presented in the literature as being sexist, mercantile, coercive and rudely technicistic, and a book on the subject should take issue with these accusations. In avoiding these topics and in failing to separate technical from ethical arguments in their opposition to IVF, Hölzle and Wiesing appear to be less than convincing.

MICHAEL H KOTTOW, Professor of Ophthalmology, University of Chile. 